\title{
Book Review ‘Tips on Grab \& Enchanting Husband Heart’ (Malay Version)
}

\section{Uqbah lqbal ${ }^{*}$}

School of History, Politics and Strategy, Faculty of Social Sciences and Humanities, UKM 43650, BangiSelangor, Malaysia

Written by Sakinah Ramli, this book can be a useful guide to the wives and prospective wives in the face of married life with her husband and children loved. Beauty is something that is desired by every human being. Similarly, a husband, he also desire a beautiful wife or at least be able to build up and look like beautiful women. Despite the varied beauty of the husband, it must be maintained because the best of beauty is a pretty manners and courtesy. Beauty has a wide interpretation and it depends on the individual. In his book entitled "Action For Success", Helen Gurley Brown reveals beauty as "Beauty can't amuse you, but brainwork - reading, writing, thinking -can."

For a teenage girl, they think of beauty is having a slim body, white skin supple and charming smile. While the boy also see beauty in the form of a handsome and well-built body. There are some beauty guidelines that should be possessed by the youth and women becoming the wife if they want to be beautiful. In young age, a teenager must have a vision of life. We must know the direction and the goals we want to achieve and have a high motivation to fulfill the wishes of both parents. Women must know the difference between good and bad things so personal beauty and dignity as a lady stand out. With attitudes like this, especially woman who are becoming wife are increasingly respected and honored by husbands. Husband will love more his wife that knows the hearts and know how to judge between good and bad.

A woman must love herself, parent, husband, in-laws and loves each of her family members. They strive to strengthen family ties, love neighbors and community members. A woman must take the opportunity to have as much knowledge as possible whether formal or not. Academic knowledge is very important for the future, to beautify the soul of spiritual knowledge and the knowledge to take care of yourself and family. Physical health must be maintained to provide the necessary rights to the body. Do activities that make healthy body. Eat a balanced and nutritious. Avoid taking something that could damage your health and mind such as smoking, alcohol and drugs. A woman must know how to respect themselves by avoiding behaviors that can cause others to lose respect. Stay away from activities and actions that are degrading themselves. Respect teachers who educate our friends in the association, the elderly, people who are older and those who are less fortunate, regardless of race and religion. Justice is one of beauty that must be practiced by every woman. It covers daily life. A woman should be fair in interaction or during deliberations. Women just can distinguish between good and bad things clearly. They can fulfill their rights and other creatures precisely, especially the rights of husband and children. Image of a beautiful woman must abstain from vices. This is because every evil is evil and evil will make our face become bad and ugly.

Education Program for Women's Health is very important and it is being actively carried out continuously by the government through electronic media, the private sector through voluntary organizations, companies print media also publishes educational material health of women and organizing workshops, seminars, forums and other. The level of knowledge about health care among women in Malaysia is high, but the sad thing is the attitude and practice of health care and disease that still reduced. Knowledge about health and disease must be followed by action to prevent, getting early treatment and a visit to a clinic or hospital as scheduled. In addition, women must be prepared to spend money to maintain health and treat disease in order to stay look beautiful in front of her husband.
*Corresponding author: Iqbal U, School of History, Politics and Strategy, Faculty of Social Sciences and Humanities, UKM 43650, BangiSelangor, Malaysia, Tel: +60389215555; E-mail: uqbah@siswa.ukm.edu.my

Received September 03, 2016; Accepted September 20, 2016; Published September 28, 2016

Citation: Iqbal U (2016) Book Review 'Tips on Grab \& Enchanting Husband Heart' (Malay Version). Intel Prop Rights. S1: 004. doi: 10.4172/2375-4516.S1-004

Copyright: @ 2016 lqbal U. This is an open-access article distributed under the terms of the Creative Commons Attribution License, which permits unrestricted use, distribution, and reproduction in any medium, provided the original author and source are credited. 